\title{
Changes in Concanavalin A agglutinability during development of the inner cell mass and trophoblast of mouse blastocysts in vitro
}

\author{
J. S. Sobel* and L. Nebel \\ Department of Embryology and Teratology, Tel-Aviv University Medical School, \\ Chaim Sheba Medical Center, Tel-Hashomer, Israel
}

\begin{abstract}
Summary. Mouse blastocyst cultures were analysed for Concanavalin A (Con A) agglutinability by microhaemadsorption methods and for Con $A$ binding capacity with Rhodamine-Con A stain. The inner cell mass, which was not agglutinable in the early culture stages, became agglutinable when it started to develop. The trophoblast, which was initially agglutinable, lost this property as the cells matured. There was no apparent correlation between changes in agglutinability and capacity to bind Rhodamine-Con A. The pattern of change in Con A agglutinability which characterized development of the inner cell mass and trophoblast is consistent with an interpretation that agglutinability was related to the migratory activities of these cells. The loss of agglutinability associated with trophoblast maturation may have been due to alterations in Con $\mathrm{A}$ receptor accessibility.
\end{abstract}

\section{Introduction}

Lectins, proteins and glycoproteins, which bind specific saccharides, have proved useful for studying cell surface changes during development (Sharon \& Lis, 1972; Nicolson, 1974). The most widely employed lectin, Concanavalin A (Con A), which recognizes $\alpha$-D-mannopyranosyl and $\alpha$-D-glucopyranosyl residues (Goldstein \& So, 1965; So \& Goldstein, 1968), induces agglutination in early embryonic cells but not in fetal or adult cells, suggesting that reactivity of Con A receptors may indicate the state of cell differentiation as reflected in the properties of the surface (Kleinschuster \& Moscona, 1972). The fact that malignant cells also tend to be more agglutinable than their normal counterparts has led to the proposal that the agglutinability of embryonic and malignant cells may be related to their motility, i.e. morphogenetic cell movements and invasiveness (Moscona, 1971). Evidence for such a relationship has been obtained in a variety of developmental systems (Kleinschuster \& Moscona, 1972; Moran, 1974; McDonough \& Lilien, 1975; Neri, Roberson, Connolly \& Oppenheimer, 1975), but the mechanisms involved in determining susceptibility to agglutination remain obscure (Ukena, Goldman, Benjamin \& Karnofsky, 1976).

Studies on early embryos have shown that the plasma membrane of the mouse egg (Pienkowski, 1974; Johnson, Eager, Muggleton-Harris \& Grave, 1975), like that of other rodents (Nicolson, Yanagimachi \& Yanagimachi, 1976), contains receptors for a variety of lectins, including Con A. Con $\mathrm{A}$ binds to the mouse egg both before and after fertilization (Pienkowski, 1974; Johnson et al., 1975), but can apparently induce agglutination only after fertilization (Pienkowski, 1974). When agglutinability was tested by adherence of embryos to each other, this property was also found during the subsequent cleavage stages, but became reduced in the morula stage and was lost in the trophoblast layer of the blastocyst but not in the isolated inner cell mass (ICM) (Rowinski, Solter \& Koprowski, 1976). Study of Con A agglutinability by haemadsorption tests showed (1) that the trophoblast layer was uniformly agglutinable in the early blastocyst stage and (2) that with the onset of trophoblast differentiation in the late blastocyst, the polar trophoblast, which overlies the ICM and gives rise to the ectoplacental cone (Gardner \& Papaioannou, 1975), became non-agglutinable while the mural trophoblast continued to be agglutinable during transformation into primary giant cells (Sobel \&

* Reprint requests to Dr. J. S. Sobel, Laboratory of Radiobiology, University of California, San Francisco, California 94143, U.S.A. 
Nebel, 1976). This previous study utilized freshly isolated embryos at different stages of development, but in the present study tests of Con A reactivity were applied to blastocysts undergoing development in vitro. Such a system permits analysis of the ICM as it begins to differentiate primary germ cell layers and of trophoblast cells as they complete their maturation.

\section{Materials and Methods}

ICR mice were induced to superovulate (Sobel \& Nebel, 1976) and were killed on Day 4 post coitum (appearance of vaginal plug designated Day 1). The zona pellucidas were removed mechanically by sucking the blastocysts in and out of a small micropipette. The Eagle's medium was supplemented with $10 \%$ heat-inactivated fetal calf serum, 100 units penicillin $/ \mathrm{ml}, 100$ units mycostatin $/ \mathrm{ml}$ and 100 $\mu \mathrm{g}$ streptomycin $/ \mathrm{ml}$. The cultures were maintained in a humidified incubator in an atmosphere of $5 \%$ $\mathrm{CO}_{2}$ and were examined for the capacity to (1) bind molecular Con A, as fluorescent Rhodamine-Con $A$, and (2) participate in cell-mediated Con A interactions. Two kinds of haemadsorption assays (Furmanski, Phillips \& Lubin, 1972) were used to demonstrate the latter. In one assay untreated cultures were tested for their ability to bind Con A-coated (indicator) erythrocytes; in the second assay Con A-coated cultured blastocysts were tested for their ability to bind untreated erythrocytes. Because indicator erythrocytes can adhere to agglutinable and non-agglutinable cells this reaction is thought to reflect the availability of Con A receptors for binding (cell-bound) Con A (Furmanski $e t$ al., 1972; Yin, Ukena \& Berlin, 1972; Branny, Sainerova \& Sovova, 1976). In contrast, adherence of untreated erythrocytes to Con A-coated cells is correlated with cell agglutinability and this haemadsorption test can serve as an assay for cell agglutination (Furmanski et al., 1972; Yin et al., 1972; Rittenhouse, Williams \& Fox, 1976).

\section{Haemadsorption assays}

Outdated erythrocytes were obtained from type O-positive donors, washed three times in Dulbecco's phosphate-buffered saline (PBS), and suspended in $2 \%(\mathrm{v} / \mathrm{v})$ PBS supplemented with $0.2 \%$ bovine serum albumin (Sigma Chemical Corp.) (PBS-A). All subsequent treatments were performed with PBS-A medium at $0^{\circ} \mathrm{C}$ unless otherwise noted. The two haemadsorption assays were based on the method of Furmanski et al. (1972).

Haemadsorption of erythrocytes to Con A-coated cells. Blastocysts were washed for $15 \mathrm{~min}$, incubated in the appropriate concentration of Con A (Miles-Yeda) for $30 \mathrm{~min}$, washed again for $30 \mathrm{~min}$ and the erythrocyte suspension added for kinetic and stationary assays. In kinetic assays the cultures were shaken at $50 \mathrm{rev} / \mathrm{min}$ in a gyratory water-bath shaker (Model G76, New Brunswick Sci. Co., Inc.) for $20 \mathrm{~min}$ at $35^{\circ} \mathrm{C}$ or for $60 \mathrm{~min}$ at $0^{\circ} \mathrm{C}$. In stationary assays the cultures were maintained for $60 \mathrm{~min}$ at $0^{\circ} \mathrm{C}$. The cultures were then carefully washed to remove non-adhering erythrocytes, fixed in $2.5 \%$ PBS-buffered glutaraldehyde, postfixed in methanol and stained with Lephene Wright-Giemsa's.

Haemadsorption of Con A-coated erythrocytes to untreated cells. Washed erythrocytes were incubated in $100 \mu \mathrm{g} \mathrm{Con} \mathrm{A} / \mathrm{ml}$ for $30 \mathrm{~min}$ at $22^{\circ} \mathrm{C}$, washed three times and resuspended at a concentration of $2 \%(\mathrm{v} / \mathrm{v})$. Blastocyst cultures were washed for $15 \mathrm{~min}$, incubated in the indicator erythrocyte suspension for $60 \mathrm{~min}$ at $0^{\circ} \mathrm{C}$ and rinsed, fixed and stained as described above.

Controls for the haemadsorption tests were prepared by treating blastocysts before or during incubation with erythrocytes in PBS-A or in Con A solution with added 0.1 M- $\alpha$-D-methylmannopyranoside.

The haemadsorption response was measured as follows. (1) In 24-h or longer cultures the response of the unattached blastocysts was calculated according to the percentage of the peripheral margin or the ICM respectively which was covered with erythrocytes. (2) For the trophoblast monolayer the haemadsorption response was calculated according to the percentage of cells which adsorbed erythrocytes. Results were scored on a scale of 0 to $++++:(+), 10 \% ;+, 10-25 \% ;++, 25-50 \%$; ,$+++ 50-75 \% ;++++, 75-100 \%$.

Trophoblast outgrowth was measured by photographing the cultures and making planimetric measurements on drawings of the film projections (Granholm \& Brenner, 1976). 


\section{Staining with Rhodamine-Con $A$}

All treatments utilized PBS-A and were performed at $0^{\circ} \mathrm{C}$. Coverslip cultures of blastocysts were washed for $15 \mathrm{~min}$, exposed to $1000 \mu \mathrm{g}$ Rhodamine-Con A (Miles-Yeda)/ml for $30 \mathrm{~min}$, washed again for $30 \mathrm{~min}$, mounted in glycerol/PBS-A $(1: 1 \mathrm{v} / \mathrm{v})$ and examined in a Reichert Fluorpan fluorescent microscope. Control cultures were examined for autofluorescence and the specificity of RhodamineCon $\mathrm{A}$ binding was determined by blocking the reaction with $0 \cdot 1 \mathrm{M}-\alpha-\mathrm{D}-$ methyl-mannopyranoside. The film for photographs was Kodak photomicrograph colour film and was processed with E3 developer to an ASA of 500.

\section{Results}

\section{Haemadsorption by blastocysts before attachment}

Blastocysts which had been maintained for $24 \mathrm{~h}$ in culture gave a positive response to both kinds of haemadsorption tests; the untreated blastocysts bound Con A-coated (indicator) erythrocytes and Con A-coated blastocysts bound untreated erythrocytes (Table 1; Pl. 1, Fig. 1). When haemadsorption was carried out at $35^{\circ} \mathrm{C}$, maximum erythrocyte adherence was obtained by 20 min with an average $75-100 \%$ of the blastocyst periphery covered by indicator erythrocytes and $25-50 \%$ of the Con A-coated blastocysts covered by untreated erythrocytes. Similar reactions were obtained at $0^{\circ} \mathrm{C}$ with extended incubation times (Table 1). There was considerable variation in the number and distribution of adhering erythrocytes and no consistent differences in haemadsorption capacities of polar and mural trophoblast could be detected. The reactions were specific, as shown by the inhibition of haemadsorption in the presence of $0 \cdot 1 \mathrm{M}-\alpha$-D-methyl-mannopyranoside.

Table 1. Concanavalin A-mediated haemadsorption of mouse blastocysts cultured for $24 \mathrm{~h}$

\begin{tabular}{lccccc}
\hline \multicolumn{1}{c}{$\begin{array}{c}\text { Assay } \\
\text { conditions }\end{array}$} & $\begin{array}{c}\text { Blastocysts treated with Con A } \\
(500 \mu \mathrm{g} / \mathrm{ml}) \text { and tested with } \\
\text { untreated erythrocytes }\end{array}$ & Control & & $\begin{array}{c}\text { Blastocysts tested with } \\
\text { indicator erythrocytes }\end{array}$ \\
\cline { 2 - 5 } $\begin{array}{l}\text { Kinetic } \\
\left(35^{\circ} \mathrm{C}, 20 \mathrm{~min}\right)\end{array}$ & $\frac{10}{10}, \frac{10}{10}, \frac{10}{10}, \frac{10}{10}++$ & $\frac{0}{12}$ & & $\frac{5}{6}, \frac{6}{6}, \frac{8}{8}++++$ & Control \\
$\begin{array}{l}\text { Kinetic } \\
\left(0^{\circ} \mathrm{C}, 60 \mathrm{~min}\right)\end{array}$ & $\frac{8}{8}, \frac{11}{11}, \frac{8}{8}+++$ & $\frac{0}{12}$ & & $\frac{8}{12}, \frac{5}{6}, \frac{5}{5}++$ & $\frac{0}{12}$ \\
$\begin{array}{l}\text { Stationary } \\
\left(0^{\circ} \mathrm{C}, 60 \mathrm{~min}\right)\end{array}$ & $\frac{3}{6}, \frac{8}{14}, \frac{8}{8}++$ & $\frac{0}{12}$ & & $\frac{5}{5}, \frac{1}{5}, \frac{8}{9}, \frac{6}{6}++$ & $\frac{0}{12}$ \\
\hline
\end{tabular}

Results are given as the ratio of the number of positive to the total number of blastocysts observed per experiment and the average degree of erythrocyte adherence scored as described in the text.

\section{Haemadsorption by blastocyst cultures during attachment and outgrowth stages}

By $48 \mathrm{~h}$ in culture most blastocysts had attached to the culture dish and trophoblast cells were beginning to spread out from the ICM (Text-fig. 1). The results of the haemadsorption tests depended on the choice of assay conditions (Table 2). Optimal response was obtained under stationary test conditions in which erythrocytes bound to most of the trophoblast cells and also to adjacent cell-free areas (Pl. 1, Figs 2, 3 and 4). (Stationary tests at $35^{\circ} \mathrm{C}$ were not feasible because of erythrocyte adherence to the plates.) With kinetic assays at 0 and $35^{\circ} \mathrm{C}$ erythrocyte adherence was usually limited to peripheral trophoblast cells and adjacent cell-free areas. The stationary assay was used to test Con $\mathrm{A}$ concentration dependence and maximal trophoblast response was observed at concentrations of 100 $\mu \mathrm{g} / \mathrm{ml}$ and above (Table 3).

In the 48-h cultures the ICM usually gave a negative response to both haemadsorption tests under all assay conditions tested (Pl. 1, Figs 3 and 4; Tables 2 and 3). 


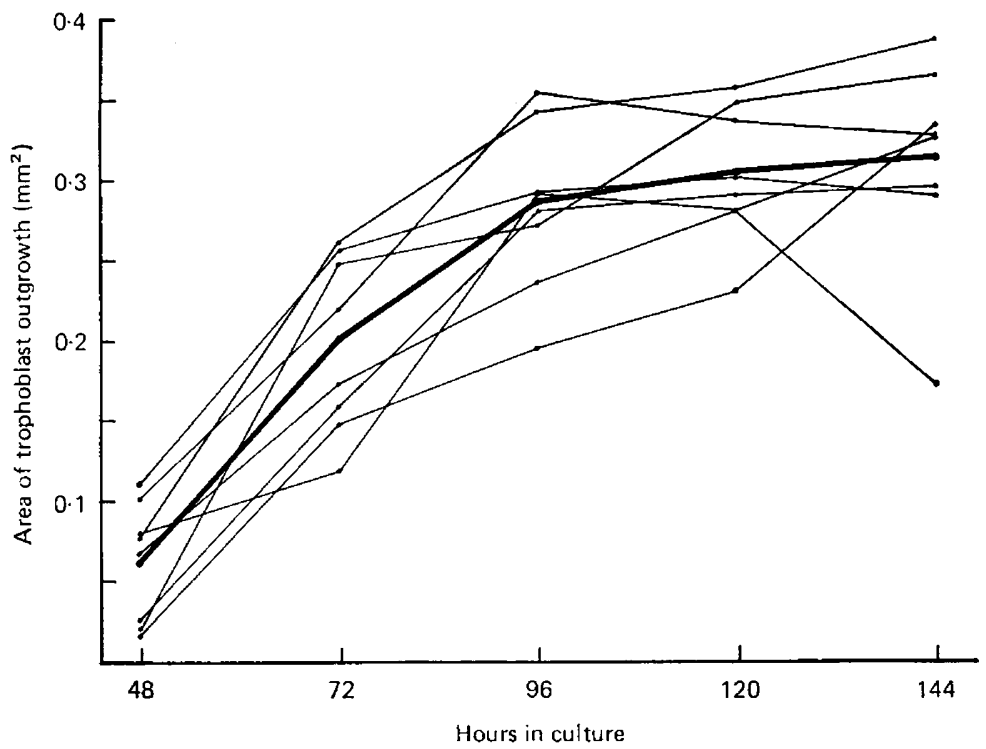

Text-fig. 1. Development of trophoblast outgrowth in 8 mouse blastocyst cultures (one experiment). All blastocysts had attached to the plate by $48 \mathrm{~h}$ and trophoblast outgrowth had started in the 5 (larger) blastocysts. The thicker line represents the mean rate of outgrowth.

Table 2. Concanavalin A-mediated haemadsorption of mouse blastocysts cultured for $48 \mathrm{~h}$

\begin{tabular}{|c|c|c|c|c|c|}
\hline \multirow{2}{*}{$\begin{array}{c}\text { Assay } \\
\text { conditions }\end{array}$} & \multirow{2}{*}{$\begin{array}{l}\text { No. of test } \\
\text { blastocysts }\end{array}$} & \multicolumn{2}{|c|}{ Inner cell mass } & \multicolumn{2}{|c|}{ Trophoblast } \\
\hline & & Test & Control & Test & Control \\
\hline Kinetic $\left(35^{\circ} \mathrm{C}, 20 \mathrm{~min}\right)$ & 54 & $(+) /+$ & $(+)$ & $(t) / t$ & $(+)$ \\
\hline Kinetic $\left(0^{\circ} \mathrm{C}, 60 \mathrm{~min}\right)$ & 33 & $(+)$ & $(+)$ & + & $(+)$ \\
\hline Stationary $\left(0^{\circ} \mathrm{C}, 60 \mathrm{~min}\right)$ & 39 & - & 一 & ++ & 一 \\
\hline
\end{tabular}

Blastocyst cultures were treated with $500 \mu \mathrm{g}$ Con $\mathrm{A} / \mathrm{ml}$ and tested with untreated erythrocytes (two experiments). Results are given as the degree of haemadsorption; scoring as described in the text.

Table 3. Concanavalin A-mediated haemadsorption of mouse blastocysts cultured for $48 \mathrm{~h}$ or $120 \mathrm{~h}$

\begin{tabular}{|c|c|c|c|c|c|c|c|}
\hline & \multicolumn{5}{|c|}{$\begin{array}{l}\text { Blastocysts treated with Con A and tested } \\
\text { with untreated erythrocytes }\end{array}$} & \multirow{2}{*}{\multicolumn{2}{|c|}{$\begin{array}{l}\text { Blastocysts tested } \\
\text { with indicator } \\
\text { erythrocytes }\end{array}$}} \\
\hline & \multicolumn{5}{|c|}{ Concentration of Con A $(\mu \mathrm{g} / \mathrm{ml})$} & & \\
\hline & Control & 10 & 50 & 100 & 500 & Control & Test \\
\hline \multicolumn{8}{|l|}{ 48-h Cultures } \\
\hline \multirow{2}{*}{ Inner cell mass } & $\underline{0}$ & $\underline{0}$ & $\mathbf{0}$ & 2 & 1 & 0 & 2 \\
\hline & $\overline{15}$ & $\overline{6}$ & $\overline{15}$ & $\overline{12}(+)$ & $\overline{16}^{+}$ & $\overline{8}$ & $\overline{18}^{+}$ \\
\hline \multirow{2}{*}{ Trophoblast } & 0 & $\underline{0}$ & $11+1$ & & & $\mathbf{0}$ & \\
\hline & $\overline{\mathbf{1 5}}$ & $\overline{4}$ & $\overline{15}++$ & $\overline{12}^{+}+$ & $\overline{16}^{++}$ & $\overline{8}$ & $\overline{19}^{+}++$ \\
\hline \multicolumn{8}{|l|}{ 120-h Cultures } \\
\hline \multirow{2}{*}{ Inner cell mass } & $\underline{0}$ & $\underline{5}(t)$ & $\underline{4}(+)$ & $\underline{15}+$ & $\underline{16}+$ & $\underline{0}$ & $\underline{5}+$ \\
\hline & $\overline{12}$ & $\overline{21}^{(+)}$ & $\overline{16}^{(+)}$ & $\overline{25}^{+}$ & $\overline{31}+$ & $\overline{8}$ & $\overline{13}+$ \\
\hline \multirow{2}{*}{ Trophoblast } & $\underline{0}$ & $\underline{0}$ & $\underline{\mathbf{0}}$ & $\frac{2}{-1}(t)$ & $13(+)$ & $\underline{0}$ & $\frac{6}{(+)}$ \\
\hline & $\overline{12}$ & $\overline{24}$ & $\overline{17}$ & $\overline{28}^{(+)}$ & $\overline{33}^{(+)}$ & $\overline{8}$ & $\overline{17}^{(T)}$ \\
\hline
\end{tabular}

Both haemadsorption tests were conducted under stationary conditions at $0^{\circ} \mathrm{C}, 60 \mathrm{~min}$. Results given as the ratios of the number of positive to the total number of cultures observed (at least 2 experiments per group) and the average degree of erythrocyte adherence was scored as described in the text. 
From $72 \mathrm{~h}$, an increasing proportion of trophoblast cells failed to bind erythrocytes in both haemadsorption tests. This change of reactivity seemed to be related to alterations in the rate of trophoblast outgrowth (Text-fig. 1). Thus, while haemadsorption was maximal when cells were actively spreading (48-72 h), it decreased as the rate of spreading slowed (72-96 h) and was absent when spreading had essentially ceased at $120 \mathrm{~h}$ (Pl. 1, Figs 5 and 6). Whereas trophoblast of 48-h cultures treated with $100 \mu \mathrm{g}$ Con $\mathrm{A} / \mathrm{ml}$ yielded maximal levels of erythrocyte adherence, the response of trophoblast in 120-h cultures was minimal, even after treatment with $500 \mu \mathrm{g} \mathrm{Con} \mathrm{A/ml} \mathrm{(Table} \mathrm{3).}$ Cell reaction was inhibited in the presence of $0 \cdot 1 \mathrm{M}-\alpha$-D-methyl-mannopyranoside.

The haemadsorption response of the ICM (Table 3) was variable and also seemed to be related to its particular growth pattern. Spherically shaped ICMs attached to stalk-like supports were nonreactive while the stalks themselves and ICMs which flattened and infiltrated into trophoblast frequently became reactive after about the 3 rd day of culture. Also reactive were small vesicles consisting of ICM-like cells which were scattered throughout the trophoblast in a few of the cultures. Erythrocyte adherence to the ICM was at first limited to a few cells on one side of the ICM-trophoblast border and gradually increased to cover more of the border area (Pl. 1, Figs 5 and 6) and, less frequently, the main body of the ICM. Haemadsorption in these cultures, as in 48-h cultures, was inhibited under kinetic test conditions (data not presented).

\section{Staining with Rhodamine-Con $A$}

Rhodamine-Con A, a red stain, was selected to identify Con A binding sites to contrast with the ICM which frequently fluoresced yellow; trophoblast exhibited minimal fluorescence. When blastocysts attached to the plate after $48 \mathrm{~h}$ in culture only the peripheral margin of the ICM took up the stain while the rest of the ICM was not reactive (PI. 2, Fig. 7). At the same time the trophoblast stained red from the earliest stage at which the cells started to spread out from the ICM (PI. 2, Fig. 8). Binding was inhibited in the presence of $0.1 \mathrm{M}-\alpha$-D-methylmannopyranoside (Pl. 2, Fig. 9). As the ICM began to grow, the enlarging peripheral margin continued to bind Rhodamine-Con A and at the same time an increasing number of cells on the ICM surface also began to take up stain, especially on the cell borders (Pl. 2, Fig. 10). Since all procedures were carried out at $0^{\circ} \mathrm{C}$, the observed staining presumably reflected binding limited to cell surfaces. Trophoblast cells continued to bind Rhodamine-Con A throughout the culture period (Pl. 2, Figs 8,11 and 12) and no consistent differences in the intensity of the stain reaction could be detected in 48-, 72-, 96- and 120-h cultures.

\section{Discussion}

The present investigation has shown striking changes in cell surface properties, as reflected by altered reactivity of Con A receptors, during development of the ICM and trophoblast in vitro. The distinctive regional pattern of Con A agglutinability which was found in 5-day uterine blastocysts (Sobel \& Nebel, 1976) was not observed in 24-h cultured blastocysts. The cultured blastocysts bound erythrocytes patchily over the entire trophoblast surface and, while there may have been a greater tendency for polar than for mural trophoblast to be non-reactive, it was clear that culture conditions did not support normal differentiation of the trophoblast surface in the majority of embryos. One possible explanation is that development of abnormal cell surface properties reflects some kind of cultureinduced alteration in the differentiated state of the trophoblast cells. Culture conditions are known to induce loss of developmental capacity in early embryos: mortality is enhanced when cultured blastocysts derived from cleavage-stage embryos are transferred to ectopic sites (Billington, Graham \& McLaren, 1968) or to the uterus of foster mothers (Bowman \& McLaren, 1970). There are no known abnormalities in structure (McReynolds \& Hadek, 1972; Solter, Biczyko, Pienkowski \& Koprowski, 1974) or metabolism (Menke \& McLaren, 1970) to account for the loss of developmental potential of cultured blastocysts, but the occurrence of the mortality before or just after implantation in some of the embryos (Bowman \& McLaren, 1970) implies disturbance in the function of the early trophoblast. One manifestation of such disturbance could be altered cell surface behaviour. 
Evidence from a variety of developmental systems indicates a relationship between Con-A agglutinability and cellular motility (Moscona, 1971; Kleinschuster \& Moscona, 1972; Moran, 1974; McDonough \& Lilien, 1975; Neri et al., 1975). If a similar relationship were present in the blastocyst cultures then agglutinability could serve as a marker for the spreading phase of trophoblast development and for ICM cells which are engaged in morphogenetic cell movements. The present experiments point to the existence of such a relationship since the trophoblast was agglutinable during spreading stages and lost agglutinability when spreading ceased, while the ICM, which was initially nonagglutinable, became agglutinable when it started to develop. The following evidence lends further support to a relationship between agglutinability and cellular motility in this system and also suggests that observations during the outgrowth stage in vitro may be correlated with events in vivo.

Firstly, cinematographic observations of blastocyst cultures have indicated the existence of two kinds of locomotory activities: ruffling membrane activity on the peripheral margin of the trophoblast outgrowth which resembles the membrane activity of surface blastomeres, and blebbing at the ICM-trophoblast margin (Granholm \& Brenner, 1976). These were also the sites most active in the haemagglutination tests.

Secondly, cultured trophoblast and ICM secrete plasminogen activator during the intervals corresponding to periods in which agglutinability was observed in the present study (equivalent to Days 6-10 of gestation for trophoblast and starting at Day 7 for ICM) (Strickland, Reich \& Sherman, 1976). The production of plasminogen activator is characteristic of migratory and invasive cells (Ossowski, Quigley, Kellerman \& Reich, 1973; Unkeless, Tobia, Ossowski, Quigley, Rifkin \& Reich, 1973). Furthermore, proteolytic activity which results from plasminogen activator secretion can induce Con A agglutinability in previously nonagglutinable cells (Whur, Kopper, Urquhart \& Williams, 1976).

Thirdly, the spreading and agglutinable phase of trophoblast development in vitro also corresponds to the period when trophoblast is invasive in utero (Kirby, 1965). Since trophoblast spreading in vitro may be analogous to invasiveness in vivo (Gwatkin, 1966; Menke \& McLaren, 1970), it is tempting to infer that Con A agglutinability may be a characteristic of both. The outer layer of the ICM, believed to be the source of endoderm (Solter \& Knowles, 1975), started to spread and became agglutinable at approximately the same time (Day $6 \frac{1}{2}$ of gestation) at which endoderm normally develops (Snell \& Stevens, 1966). The distal endoderm consists of a migratory population of cells which spread out to form the lining of the trophectoderm and it seems possible that the observed agglutinability of the ICM could have been due to the development of these cells.

To determine to what extent agglutinability may have been influenced by experimental conditions, the effects of temperature and kinetic and stationary conditions were tested. The trophoblast coat of the unattached blastocyst and the trophoblast cells of the early spreading cultures were both agglutinable in stationary assays but only the trophoblast of the unattached blastocyst was agglutinable in kinetic assays, perhaps because of the different physical conditions of the two systems. In kinetic assays the blastocyst was a relatively large spherical body floating in the erythrocyte suspension, while in the stationary assays the spreading cells formed a monolayer on the bottom of the culture dish. In contrast, an intrinsic difference in agglutinability among the flattened trophoblast cells probably accounted for the fact that most of the monolayer was agglutinable under stationary conditions but usually only the peripheral trophoblast cells were agglutinable under kinetic conditions. Sensitivity to shear forces may account for the reported absence of blastocyst agglutinability when agglutinability was measured by adherence of embryos which could not be disaggregated by pipetting (Rowinski et al., 1976).

Con $\mathrm{A}$ agglutinability may be influenced by many interrelated factors such as the number of Con A binding sites (Burger, 1969, 1973), and their lateral mobility in the plane of the membrane (Singer \& Nicolson, 1972; Rosenblith, Ukena, Yin, Berlin \& Karnofsky, 1973), as well as the general morphology (van Blitterswijk, Walborg, Feltkamp, Hilkman \& Emmelot, 1976; Collard \& Temmink, 1976; Temmink, Collard, Roosien \& van den Bosch, 1976) and mitotic (Shoham \& Sachs, 1974; Smets \& Delay, 1974) state of the cells. In the present study the reaction of the trophoblast cells with Rhodamine-Con A, assumed to be a measure of binding capacity, remained relatively constant while the cells were changing from an agglutinable to a non-agglutinable state. This suggests that agglutin- 
ability in these cells was probably not limited by the number of Con A binding sites. Lack of correlation between Con A agglutinability and binding capacity has also been described at other stages of development (Pienkowksi, 1974; Martinozzi \& Moscona, 1975). Some kind of relationship between Rhodamine-Con A staining and haemadsorption may have been present at the ICM-trophoblast border where the cells gave a positive response to both tests. It seems likely, however, that a more complex relationship existed than a simple connection between the number of binding sites and agglutinability because most ICMs in the 120 -h culture exhibited the staining reaction but only about $50 \%$ were agglutinable (Table 3 ). Studies with other methods of analysis of Con A binding may resolve these questions.

The mobility of the receptor sites was apparently not a determining factor in the agglutinability of the ICM or trophoblast because maximum agglutinability was observed at $0^{\circ} \mathrm{C}$. This is in agreement with the findings of Gordon \& Marquardt (1974) who suggested that agglutinability may in some cases be a temperature-insensitive process which requires extended incubation times for its detection.

Various factors may have influenced agglutinability in the present experiments. (1) Cell proliferation. The ICM was undergoing proliferation during development and agglutinability is known to be cell-cycle dependent (Shoham \& Sachs, 1974; Smets \& Delay, 1974), but this consideration would presumably not apply to the trophoblast which consisted mostly of post-mitotic giant cells. (2) Membrane plasticity. Agglutinability was sensitive to kinetic disruption and this response seems to be correlated with cell surface rigidity (Gibson, Marquardt \& Gordon, 1975; van Blitterswijk et al., 1976; Collard \& Temmink, 1976). (3) Change in receptor accessibility. This could have been due to the presence of coating material on the cell surface (Noonan \& Burger, 1973) or to topographic surface alterations (Willingham \& Pastan, 1975; Temmink et al., 1976). Lack of receptor accessibility could account for the inability of trophoblast cells to bind Con A-coated (indicator) erythrocytes, a reaction believed to reflect the simple binding of Con A to its receptor (Furmanski et al., 1972; Yin et al., 1972; Branny et al., 1976). However, the fact that trophoblast cells could bind Rhodamine-Con $A$ at the same time that they were incapable of binding indicator erythrocytes would imply that any loss in accessibility would be of a partial nature which permits receptors to interact with Con A in solution but not with cell-bound Con $\mathrm{A}$.

The trophoblast lost the capacity to participate in Con A-mediated haemadsorption reactions at the same stage of development and under similar culture conditions in which it is reported to be nonantigenic (Heyner, 1973; Jenkinson \& Billington, 1974; Muggleton-Harris \& Johnson, 1976). There is conflicting evidence whether lack of trophoblast antigenicity is due to intrinsic lack of antigen (Simmons, Cruse \& McKay, 1967; Searle, Jenkinson \& Johnson, 1975) or whether antigen is present but masked (Kirby, Billington, Bradbury \& Goldstein, 1964; Currie, van Doorninck \& Bagshawe, 1968). The results of the present study suggest that trophoblast maturation is associated with cell surface changes in which the availability of surface receptors becomes altered.

We thank Dr Nechama Kosower for critical reading of the manuscript. This study was supported in part by a grant for established investigators from the Chief Scientist's Bureau, Ministry of Health, Israel.

\section{References}

Billington, W.D., Graham, C.F. \& Mclaren, A. (1968) Extra-uterine development of mouse blastocysts cultured in vitro from early cleavage.J. Embryol. exp. Morph. 20, 391-400.

BOWMAN, P. \& MCLAREN, A. (1970) Viability and growth of mouse embryos after in vitro culture and fusion. J. Embryol. exp. Morph. 23, 693-704.

Branny, J., Sainerova, H. \& Sovova, V. (1976) Haemadsorption of human erythrocytes coated with Concanavalin A on normal, transformed and hybrid cells. Folia biol., Praha 221, 20-24.
BURGER, M. (1969) A difference in the architecture of the surface membrane of normal and virally transformed cells. Proc. natn. Acad. Sci. U.S.A. 62, 994-1001.

Burger, M. (1973) Surface changes in transformed cell detected by lectins. Fedn Proc. Fedn Am. Socs exp. Biol. 32, 91-101.

Collard, J.G. \& Temmink, J.H.M. (1976) Surface morphology and agglutinability with Concanavalin $\mathrm{A}$ in normal and transformed murine fibroblasts. $J$. Cell Biol. 68, 101-112. 
Currie, G.A., van Doorninck, W. \& Bagshawe, K.D. (1968) Effect of neuraminidase on the immunogenicity of early mouse trophoblast. Nature, Lond. 219, 191-192.

Furmanski, P., Phillips, P.G. \& Lubin, M. (1972) Cell surface interactions with Concanavalin $A$ : determination by microhaemadsorption. Proc. Soc. exp. Biol. Med. 140, 216-219.

Gardner, R.I. \& Papaloannou, V.E. (1975) Differentiation in the trophectoderm and inner cell mass. In The Early Development of Mammals, pp. 107-132. Eds M. Balls \& A. E. Wild. Cambridge University Press.

Gibson, D., Marquardt, M.D. \& Gordon, J.A. (1975) Cell rigidity: effect on Concanavalin A-mediated agglutinability of fibroblasts after fixation. Science, N. Y. 189, 45-46.

Goldstein, I.J. \& So, L.L. (1965) Protein carbohydrate interactions. III. Agar gel diffusion studies on the interaction of Concanavalin A, a lectin isolated from Jack Bean, with polysaccharides. Arch. Biochem. Biophys. 111, 407-414.

Gordon, J.A. \& MARQuardT, M.D. (1974) Factors affecting haemagglutination by Concanavalin $A$ and soybean agglutinin. Biophys. biochim. Acta 332, 136144.

Granholm, N.H. \& Brenner, G.M. (1976) Effect of cytocholasin B (CB) on the morula-to-blastocyst transformation and trophoblast outgrowth in the early mouse embryo. Expl Cell Res. 101, 143-153.

Gwatkin, R.B.L. (1966) Amino acid requirements for attachment and outgrowth of the mouse blastocyst in vitro.J. cell. Physiol. 68, 335-343.

HEYNER, S. (1973) Detection of H-2 antigens on the cells of the early mouse embryo. Transplantation 16, 675677.

Jenkinson, E.J. \& Billington, W.D. (1974) Differential susceptibility of mouse trophoblast and embryonic tissue to immune cell lysis. Transplantation 18, 286289.
Johnson, M.H., Eager, D., Muggleton-Harris, A. \& Grave, H.M. (1975) Mosaicism in organization of Concanavalin A receptors on surface membrane of mouse egg. Nature, Lond. 257, 321-322.

KIRBY, D.R.S. (1965) "The invasiveness" of the trophoblast. In The Early Conceptus, Normal and Abnormal, pp. 63-78. Ed. W. W. Park. Edinburgh University Press, Edinburgh.

Kirby, D.R.S., Billington, W.D., Bradbury, S. \& Golostein, D.J. (1964) Antigen barrier of the mouse placenta. Nature, Lond. 204, 548-549.

KLeinschuster, S.K. \& MosconA, A.A. (1972) Interactions of embryonic and fetal neural retina cells with carbohydrate-binding phytoagglutinins: cell surface changes with differentiation. Expl Cell Res. 70, 397410.

Martinozzi, M. \& Moscona, A.A. (1975) Binding of I $^{25}$ Concanavalin A and agglutination of embryonic retina cells. Expl Cell Res. 94, 253-266.

McDonough, J. \& Lilien, J. (i975) Spontaneous and lectin-induced redistribution of cell surface receptors on embryonic chick neural retina cells. J. Cell Sci. 19, 357-368.

McReynoldo, H.D. \& HadeK, R. (1972) A comparison of the fine structure of late mouse blastocysts developed in vivo and in vitro. J. exp. Zool. 182, 95-118.

Menke, T.M. \& MCLAREN, A. (1970) Mouse blastocysts grown in vivo and in vitro: carbon dioxide production and trophoblast outgrowth. J. Reprod. Fert. 23, 117127.

MORAN, D. (1974) The inhibitory effect of Concanavalin $A$ on the development of the amphibian embryo. $J$. exp. Zool. 188, 361-365.

MosconA, A.A. (1971) Embryonic and neoplastic cell surface; availability of receptors for Concanavalin $\mathbf{A}$ and wheat germ agglutinin. Science, N.Y. 171, 905907.

Muggleton-Harris, A.D. \& Johnson, M.H. (1976) The nature and distribution of serologically detect-

\section{EXPLANATION OF PLATES}

\section{PLATE 1}

Con A-mediated haemadsorption of blastocyst cultures (stationary assays, $0^{\circ} \mathrm{C}, 60 \mathrm{~min}$ ). The blastocysts in Figs 1, 2, 3, 5 and 6 were treated with $500 \mu \mathrm{g}$ Con $\mathrm{A} / \mathrm{ml}$ and tested with untreated erythrocytes; the blastocyst in Fig. 4 was tested with indicator erythrocytes.

Fig. 1. Culture for $24 \mathrm{~h}$ : the left blastocyst shows erythrocyte binding to parts of the mural and polar trophoblast and the right blastocyst shows binding to part of the mural trophoblast. Glutaraldehyde fixation, $\times 150$. Fig. 2. Cultures for $48 \mathrm{~h}$. Blastocysts have attached to the culture dish and trophoblast cells are beginning to spread out. Erythrocytes adhere to the trophoblast periphery and to cell-free adjacent areas. Glutaraldehyde fixation, $\times 150$.

Fig. 3. Culture for 48 h. A more advanced stage than in Fig. 2, the trophoblast has spread out to form a monolayer and exposed a central group of small, dark-staining cells (ICM). Erythrocytes adhere to most of the trophoblast cells, the cell-free periphery, but not to the ICM. Lephene Wright-Giemsa's, $\times 150$.

Fig. 4. Culture for $48 \mathrm{~h}$. Same stage of development as blastocyst in Fig. 3. Indicator erythrocytes cover the trophoblast monolayer and adjacent cell-free areas but do not adhere to the central ICM. Glutaraldehyde fixation, $\times 150$.

Fig. 5. Culture for $120 \mathrm{~h}$. Erythrocytes adhere to the peripheral margin of the ICM and ICM-trophoblast border area. Surrounding trophoblast cells are mostly nonreactive. Lephene Wright-Giemsa's, $\times 150$.

Fig. 6. Culture for $120 \mathrm{~h}$. Only a few erythrocytes adhere to the trophoblast and most of the cells are nonreactive. Erythrocytes bind to cell-free areas and part of the ICM peripheral margin. Lephene WrightGiemsa's, $\times 60$. 

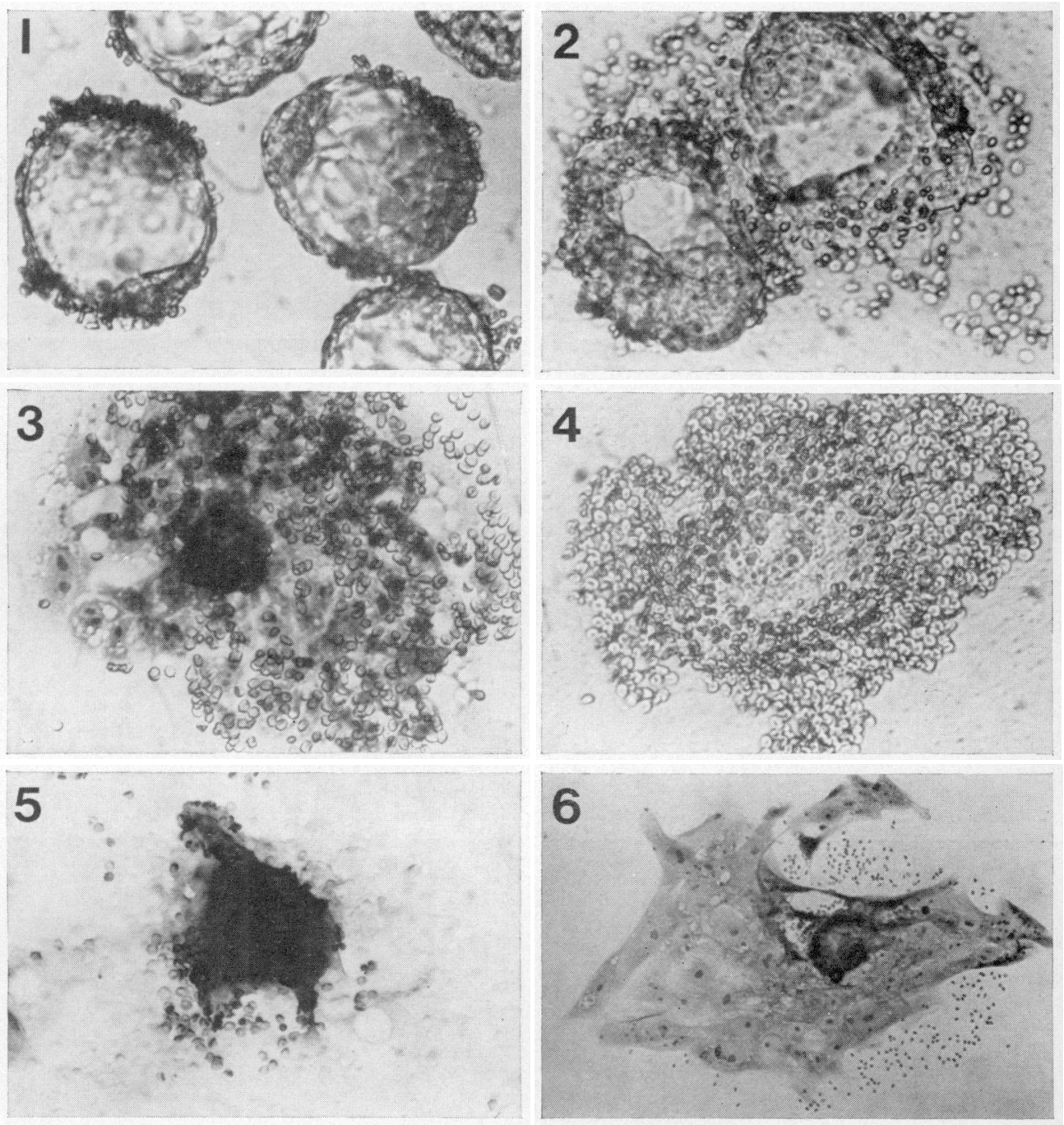


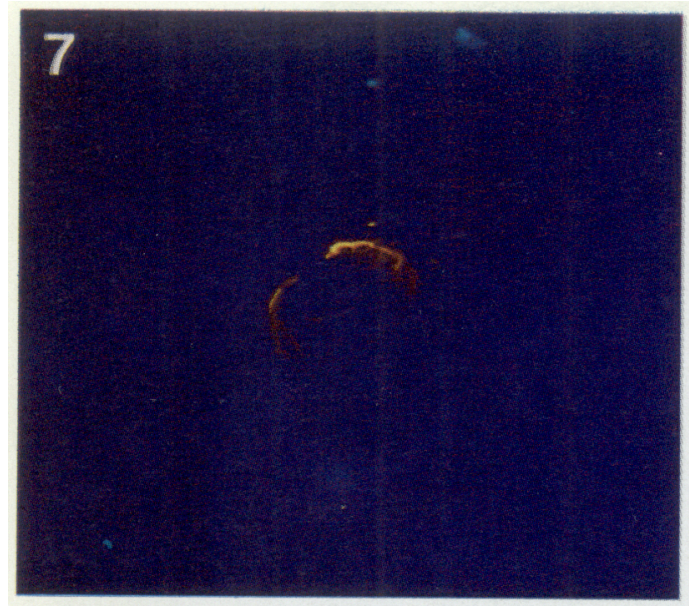

\section{0}

8
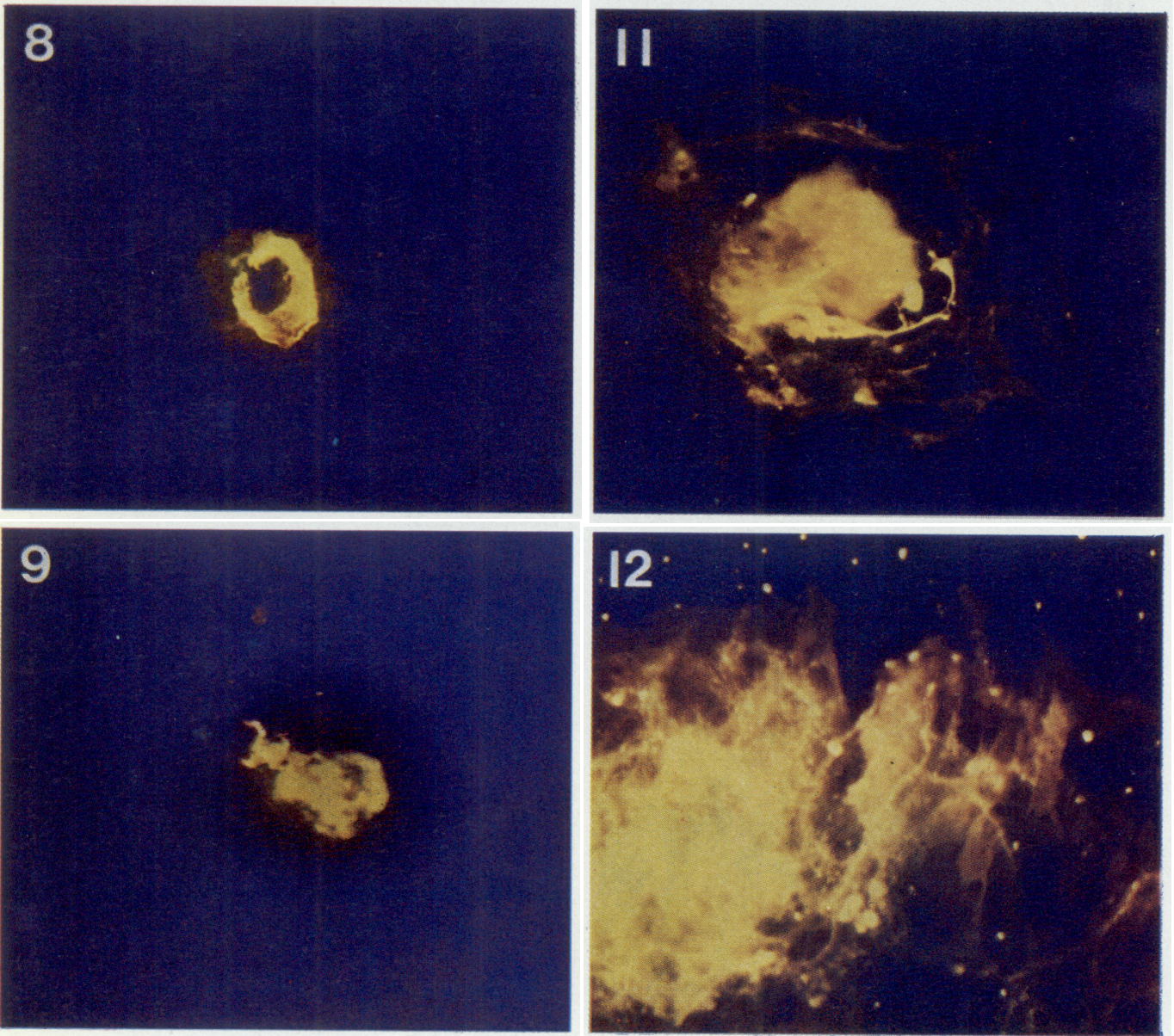
able alloantigens on the preimplantation mouse embryo. J. Embryol. exp. Morph. 35, 59-72.

Neri, A., Roberson, M., Connolly, D.T. \& OppenHEIMER, S.B. (1975) Quantitative evaluation of con A receptor site distribution on specific populations of embryonic cells. Nature, Lond. 258, 342-344.

Nicolson, G.L. (1974) The interactions of lectins with animal cell surfaces. Int. Rev. Cytol. 39, 90-190.

Nicolson, G.L., Yanagimachi, R. \& Yanagimachi, H. (1976) Ultrastructural localization of lectin-binding sites on the zonae pellucidae and plasma membranes of mammalian eggs. J. Cell Biol. 66, 263-274.

NoOnan, J. \& Burger, M. (1973) Binding of ${ }^{3}$ H Concanavalin $A$ to normal and transformed cells. J. biol. Chem. 248, 4286-4292.

Ossowskı, L., Quigley, L.P., Kellerman, G.M. \& REICH, E. (1973) Fibrinolysis associated with oncogenic transformation; requirement of plasminogen for correlated changes in cellular morphology, colony formation in agar and cell migration. J. exp. Med. 138, 1056-1064.

Pienkowski, M. (1974) Study of the growth regulation of preimplantation mouse embryos using concanavalin A. Proc. Soc. exp. Biol. Med. 145, 464-469.

Rittenhouse, H.G., Williams, R.E. \& Fox, C.F. (1976) Agglutination of a transformed mouse cell line and a variant subline with Concanavalin $\mathrm{A}$ : effect of temperature and times of lectin incubation. Biochem. biophys. Res. Commun. 71, 975-983.

Rosenblith, J., Ukena, T., Yin, H., Berlin, R. \& KARNOFSKY, M. (1973) A comparative evaluation of the distribution of Concanavalin A-binding sites on the surfaces of normal, virally-transformed and protease-treated fibroblasts. Proc. natn. Acad. Sci. U.S.A. 70, 1625-1629.

Rowinski, J., SOlter, D. \& KopRowski, H. (1976) Changes in Concanavalin $\mathbf{A}$ induced agglutinability during preimplantation mouse development. Expl Cell Res. 100, 404-408.

Searle, R.F., Jenkinson, E.J. \& Johnson, M.H. (1975) Immunogenicity of mouse trophoblast and embryonic sac. Nature, Lond. 255, 719-720.
Sharon, M. \& Lis, J. (1972) Lectins: cell agglutinating and sugar specific proteins. Science, N.Y. 177, 949959.

Shoham, J. \& SaChs, L. (1974) Different cyclic changes in the surface membrane of normal and malignant cells. Expl Cell Res. 85, 8-14.

Simmons, R.L., Cruse, V. \& McKay, D.G. (1967) The immunologic problem of pregnancy: II. Ultrastructure of isogeneic and allogeneic trophoblast transplants. Am. J. Obstet. Gynec. 97, 218-230.

Singer, S.J. \& Nicolson, G.L. (1972) The fluid mosaic model of the structure of cell membranes. Science, N.Y. 175, 720-731.

Smets, L.A. \& Delay, L. (1974) Cell cycle dependent modulation of the surface membrane of normal and SV40 transformed 3T3 cells. J. cell. Physiol. 84, 343348.

Snell, G.D. \& Stevens, L.S. (1966) Early embryology. In Biology of the Laboratory Mouse, pp. 205-245. Ed. L. Green. McGraw-Hill, New York.

So, L.L. \& Goldstein, I.J. (1968) Protein carbohydrate interactions. XIII. The interaction of Concanavalin A with $\alpha$-mannons from a variety of microorganisms. J. biol. Chem. 243, 2003-2007.

Sobel, J.S. \& Nebel, L. (1976) Concanavalin A agglutinability of developing mouse trophoblast. J. Reprod. Fert. 47, 399-402.

SOLTER, D. \& KNOWLEs, B.B. (1975) Immunosurgery of mouse blastocysts. Proc. natn. Acad. Sci. U.S.A. 72, 5099-5102.

Solter, D., Biczysko, W., Pienkowski, M. \& KoprowSKI, H. (1974) Ultrastructure of mouse egg cylinders developed in vitro. Anat. Rec. 180, 263-297.

Srrickland, S., Reich, E. \& Sherman, I. (1976) Plasminogen activator in early embryogenesis: enzyme production by trophoblast and parietal endoderm. Cell 9, 231-240.

Temmink, J.H.M., Collard, J.G., Roosien, J. \& van DEN BosCH, J.F. (1976) Surface morphology and agglutination of lectin treated human lymphocytes and lymphoblasts. J. Cell Sci. 21, 563-578.

\section{EXPLANATION OF PLATES}

\section{PLATE 2}

\section{Rhodamine-Con A-stained blastocyst cultures.}

Fig. 7. Culture for $48 \mathrm{~h}$, equivalent in development to blastocysts in Pl. 1, Figs 3 and 4. Focus is on the ICM. This is one of the small number of cultures in which the ICM showed minimal yellow fluorescence and the light Rhodamine-Con A red stain on the peripheral margin of the ICM is more easily seen. The rest of the ICM surface does not stain red. $\times 100$.

Fig. 8. Culture for $48 \mathrm{~h}$, equivalent in development to blastocyst in Pl. 1, Fig. 2. Central dark area is the blastocoele which is surrounded by yellow fluorescing cells. Focus is on the trophoblast cells which are just starting to spread out and stain red with Rhodamine-Con A. $\times 100$.

Fig. 9. Culture for $48 \mathrm{~h}$, equivalent in development to blastocysts in Pl. 1, Figs 3 and 4 . This is a control culture treated with Rhodamine-Con $A$ and $0 \cdot 1$ M- $\alpha$-D-methylmannopyranoside. The ICM fluoresces yellow. Focus is on surrounding trophoblast monolayer which has been prevented from taking up the stain. $\times 100$. Fig. 10. Culture for $120 \mathrm{~h}$. Focus is on the surface cells of the ICM. The underlying mass of the ICM fluoresces yellow. The small surface cells stain with Rhodamine-Con A, especially at the cell margins. $\times 100$.

Fig. 11. Culture for $96 \mathrm{~h}$. The central ICM mass fluoresces yellow. Focus is on the peripheral trophoblast monolayer which stains red with Rhodamine-Con A. The mesh-like appearance of trophoblast is due to cells which have not stained at the cell surface areas overlying nuclear regions. $\times 100$.

Fig. 12. Culture for $120 \mathrm{~h}$. The ICM fluoresces yellow. Focus is on the trophoblast which stains red with Rhodamine-Con A. $\times 250$. 
Ukena, T.E., Goldman, E., Benjamin, T.L. \& KARNOFSKY, M.J. (1976) Lack of correlation between agglutinability, the surface distribution of Con $A$ and post-confluence inhibition of cell division in ten cell lines. Cell 7, 213-222.

UNkeless, J.C., Tobia, A., Ossowski, L., QUigley, J.P., RIFKIN, D.B. \& REICH, E. (1973) An enzymatic function associated with transformation of fibroblasts by oncogenic viruses. 1. Chick embryo fibroblast cultures transformed by avian RNA tumor viruses. $J$. exp. Med. 137, 85-111.

van Blitterswijk, W.J., Walborg, E.F., Feltkamp, C.A., Hilkmann, H.A.M. \& Emmelot, P. (1976) Effect of glutaraldehyde fixation on lectin mediated agglutination of mouse leukemia cells. J. Cell Sci. 21, 597-594.

Willingham, M.C. \& Pastan, I. (1975) Cyclic AMP modulates microvillus formation and agglutinability in transformed and normal mouse fibroblasts. Proc. natn. Acad. Sci. U.S.A. 72, 1263-1267.

Whur, P., Koppel, H. URQuhart, C. \& Williams, D.C. (1976) Plasmin-mediated agglutination by Concanavalin A of $3 \mathrm{~T} 3$ cells cocultured with SV40-3T3 transformants. Nature, Lond. 260, 709-710.

YIN, H.H., UKENA, T.E. \& BeRLIN, R.D. (1972) Effect of colchicine, colcemid, and vinblastine on the agglutination, by concanavalin $A$, of transformed cells. Science, N.Y. 178, 867-868.

Received 3 June 1977 